\title{
PREMA LEKSIKONU HRVATSKOG I SRPSKOG PROSVJETITELJSTVA Urednički predgovor
}

\section{Drago Roksandić}

7 bornik Hrvati i Srbi u Habsburškoj Monarhiji u 18. stoljeću: interkulturni aspekti 'prosvijećene' modernizacije sadržava autorske članke koji su nastali na temelju pojedinačnih $\triangle$ priopćenja i rasprave na istoimenom kolokviju. ${ }^{1}$ Iako su od održavanja skupa protekle skoro tri godine te iako je većina članaka napisana prije dvije godine, sadržaj ovog zbornika je istraživački aktualan pa i provokativan u intelektualnom i kulturnom smislu. Njime je markiran dio puta koji bi trebalo prijeći prije dolaska na zajednički dogovoreni cilj skupine zagrebačkih i beogradskih povjesničara različitih specijalnosti, a to je Leksikon hrvatskog $i$ srpskog prosvjetiteljstva. U pozivnom pismu koje su u proljeće 2011. godine potpisali (tada) doc. dr. sc. Zrinka Blažević, prof. dr. sc. Nikola Samardžić i urednik ovog izdanja pored ostalog je stajalo: «Polazeći od uvjerenja da hrvatsko-srpske interferencije treba istraživati u širem regionalnom okviru i dugoj povijesnoj perspektivi, ovaj bilateralni program nastoji propitati društvene, političke, ekonomske i kulturne promjene izazvane procesom "prosvijećene modernizacije” u okviru Habsburške Monarhije tijekom 18. stoljeća. Pritom je naglasak na interkulturnim, komparativnim i translacijskim aspektima toga procesa. Unutar istog obzorja zamišljeni su priprema i objavljivanje Leksikona hrvatskog i srpskog prosvjetiteljstva sa ciljem da se na tragu intelektualnohistorijske tradicije njemačke Begriffsgeschichte pruži pregled temeljnih koncepata društvenog, političkog, ekonomskog i kulturnog jezika "prosvijećene modernizacije» u Habsburškoj Monarhiji u 18. stoljeću s težištem na hrvatskoj i srpskoj baštini.» Nasuprot duboko ukorijenjenim uvjerenjima o hrvatskoj i srpskoj povijesti i kulturi kao o dva različita svijeta, ovom prilikom pošlo se od činjenice da su u ranome novom vijeku - ne previđajući sve što ih dijeli - hrvatska i srpska povijest i kultura mnogostruko isprepletene u habsburškom, mletačkom i osmanskom "kontekstu, kao što su međusobno isprepletene i povijesti Habsburške Monarhije, Mletačke Republike i Osmanskog Carstva. Regionalni epicentri epohalnih promjena u 18. stoljeću su nesumnjivo u Habsburškoj Monarhiji, kao što su to i u hrvatskom slučaju u habsburškom podaništvu, ali od kraja 17. i početka 18. stoljeća i u srpskom slučaju isto tako u Habsburškoj Monarhiji. Ove činjenice se ne bi smjelo simplificirano instrumentalizirati jer je mnogo toga što Hrvate i Srbe u istom podaništvu u to doba više dijeli nego povezuje. Međutim,

Kolokvij je održan u Zagrebu, u Vijećnici Filozofskog fakulteta Sveučilišta u Zagrebu, u petak i subotu, 11. i 12. studenog 2011. godine u organizaciji Odsjeka za povijest i Centra za komparativnohistorijske i interkulturne studije Filozofskog fakulteta Sveučilišta u Zagrebu te Odeljenja za istoriju Filozofskog fakulteta Univerziteta u Beogradu. Njime je zaključen dvogodišnji bilateralni hrvatsko-srpski program pod istim naslovom, koji su zajednički utemeljili znanstveni projekti „Triplex Confinium - hrvatska višegraničja u euromediteranskom kontekstu“ $s$ hrvatske strane i „Modernizacija zapadnog Balkana“ sa srpske strane. Financirale su ga na temelju bilateralnog sporazuma Vlada Republike Hrvatske i Vlada Republike Srbije. Vidjeti: Colloquia 1/2011. (http://kula-jankovica.unizg.hr/hr/desnicinisusreti/izdanja-centra/biblioteka-colloquia/). 
to ima mnogo više smisla reći za 1700 . nego za 1800 . godinu, bar kada je riječ o vrijednosnim orijentacijama i razvojnim izazovima koje jedni i drugi dijele sa svima ostalima u Srednjoj Europi. U prosvjetiteljskom obzorju bilo je moguće misliti i raditi relativizirajući temeljne vrijednosti, institucije i prakse „starog poretka“ i s hrvatske i sa srpske strane te usmjerujući kreativne potencijale s obje strane prema, u konačnici, društveno općeprihvatljivim ciljevima. Izlišno je podsjećati da habsburška „prosvijećena modernizacija“ nikada nije bila idilično percipirana čak ni među svojim najgorljivijim suvremenim pristašama, ali bi nepravedno bilo previdjeti da danas nema naroda koji sudjeluje u habsburškoj baštini a da upravo „prosvijećenoj modernizaciji“ nešto važno ne duguje. Hrvati i Srbi možda i više nego drugi jer su upravo u to doba počeli shvaćati, svaki na svoj način, da život na „predziđu“ nije jedini mogući život u modernoj Europi. Mnogobrojni detalji tog samoosvješćivanja još uvijek nisu istraženi i propitani, a još manje znamo o tome što se sve zbivalo u novim dinamikama hrvatsko-srpskih/srpsko-hrvatskih odnosa. Naslućujemo jedino to da bar kada je riječ o procesima dugog trajanja ključ za brojne potonje probleme njihovih međusobnih odnosa treba tražiti u dobu koje ih je - činilo se - dotad najviše povezivalo. U tom smislu bi Leksikon hrvatskog $i$ srpskog prosvjetiteljstva mogao biti, legitimacijski i reprezentacijski, europski vrijedan projekt. Ovaj zbornik doprinos je kretanju k tom cilju.

Kakva je njegova stvarna vrijednost reći će, nadajmo se, kritika - prije svega s hrvatske i srpske strane. To je jedan od razloga zašto kumulativna recenzija ovog zbornika prije ulaganja u tisak nije naručena. K tome, uvršteni članci su problemski i disciplinarno toliko raznovrsni da je lajtmotiv „prosvijećene modernizacije” u Hrvata i Srba u habsburškom podaništvu u 18. stoljeću održiv samo kao njihov okvir. Više smisla bi sigurno imale recenzije pojedinih priloga u zborniku, ali bi time manje-više došla u pitanje koncepcija kolokvija, a susljednično i zbornika pa i smisao samog projekta. Pored toga, kolokvij je bio zamišljen i realiziran kao jedan od dva planirana. (Sljedeći bi trebao biti održan u Beogradu.) Oba kolokvija bi trebala biti u funkciji načelno dogovorenog finalnog produkta projektne suradnje - spomenutoga komparatističkog i interkulturnog Leksikona hrvatskog i srpskog prosvjetiteljstva. Dogovoreno je bilo najprije raspraviti na kolokvijima temeljnu konceptualnu problematiku te obostrano osigurati kvalificirane uvide u istraživanja 18. stoljeća u obje historiografije i u srodnim društveno-humanističkim područjima te, potom, definirati spomenuti leksikon po svim uobičajenim kriterijima, uključujući pojmovnik (u smislu abecedara).

Izostanak recenzija ne znači, duboko sam uvjeren, da je riječ o manje vrijednom izdanju u znanstvenom smislu. Naprotiv. Zbornik uključuje niz dragocjenih priloga, koji su sigurno poticajni i unutar vlastitih kulturnih horizonata, a ne samo u hrvatsko-srpskom/srpskohrvatskom kontekstu te, dijelom, u kontekstu istraživanja povijesti Habsburške Monarhije u 18. stoljeću. Zanimljivi su kako prilozi s ambicijom inoviranog postavljanja temeljnih epohalnih pitanja, tako i - a možda i više - prilozi koji poznate probleme raspravljaju s novim, empirijski potkrijepljenim pristupima. Raznolikost zbornika čine i poneki radovi kojima bi pojedinačne recenzije vjerojatno pomogle da budu kvalitetniji. Najvažnije je ipak, naglašavam, da se svi članci tematski nalaze unutar prethodno usuglašenog okvira i da su beziznimno predlošci za daljnje rasprave.

Prema prethodnom dogovoru dr. sc. Ivana Horbec iz Hrvatskog instituta za povijest je već tada skicirala neke važne elemente Leksikona hrvatskog i srpskog prosvjetiteljstva. Napravila je i razmjerno opsežan abecedarij koji je sadržavao njezino razumijevanje ključnih pojmova. Danas se samo možemo suglasiti s prijedlogom kolegice Horbec da se spomenuti Leksikon koncepcijski kritički može orijentirati prema Handbuch politisch-sozialer Grundbe- 
griffe in Frankreich 1680-1820 (Oldenbourg 1985.-1995.; prikaz ima i na gbooks), gdje su za pojedine pojmove objavljeni radovi veličine 10-30 kartica sa znanstvenim aparatom itd. Ovaj Handbuch je uslijedio, kao što je dobro poznato, kapitalnom Geschichtliche Grundbegriffe: Historisches Lexikon zur politisch-sozialen Sprache in Deutschland (1972.-1997). Slični su projekti manje-više realizirani i drugdje tako da ovaj Leksikon ne bi bio novum bez presedana, ali bi se - u slučaju uspjeha - mogao integrirati u jedan od ključnih razvojnih trendova u europskoj historiografiji. Vrline bi mu mogle biti komparatistika i interkulturalizam. Kasnije pisane reakcije prof. dr. sc. Zorana Kravara, dr. sc. Milana Ristovića i Dragane Grbić te brojni usmeni komentari, ali napose i prilozi u ovom zborniku svjedočanstvo su da je projekt imao važne inicijalne podrške. ${ }^{2}$ Zasad su najviše zakazale države, Republika Hrvatska i Republika Srbija, jer više ne financiraju ovakve projekte. To ne znači da neće, a ne znači da nema drugih mogućnosti da se s njime krene dalje. Objavljivanje ovog zborni$\mathrm{ka}$, ponavljam, sigurno je doprinos u tom smjeru.

U inicijalnoj fazi rada na ovom zborniku važan je bio udio kolege Mladena Medveda, tada diplomskog studenta na ranonovovjekovnom modulu, a sada doktoranda na Srednjoeuropskom sveučilištu u Budimpešti te, u manjoj mjeri, kolegice Ivane Krizmanić, diplomske studentice na istom modulu, koja je u međuvremenu također diplomirala. U posljednje vrijeme pomogao je i kolega Vedran Muić, sada već diplomirani povjesničar. Inicijalna podrška prof. dr. sc. Zrinke Blažević bila je vrlo važna.

Međutim, tek u posljednjih nekoliko mjeseci - zahvaljujući prije svega kolegi Borisu Bui, uredniku izdavačke službe FF press i njegovim suradnicima, posao na pripremi rukopisa za tisak je krenuo onako kako je to bilo nužno da knjiga izađe. Vrlo sam im zahvalan zbog toga. Što sam više radio na rukopisima članaka, neovisno o imperativima mnoštva uredničkih provjera i intervencija, bio sam uvjereniji da zbornik mora izaći. Rad na Imenskom kazalu, koji sam obavio u suradnji s dr. sc. Jadrankom Brnčić, definitivno me je uvjerio da se na stranicama zbornika okupilo inspirativno društvo. Preostali raspoloživi novac u projektu Triplex Confinium iskorišten je za tiskarske troškove.

U Zagrebu, 30. rujna 2014.

2 Mirjana D. Stefanović je inače objavila Leksikon srpskog prosvetiteljstva (Službeni glasnik, Beograd 2009., 326 str.). Analogno djelo s hrvatske strane još uvijek ne postoji. Međutim, potreba za leksikonom o kojem je ovdje riječ time ne postaje ništa manja. Naprotiv. 